\title{
Quality Characteristics of Common Carp Fish Pastirma
}

\author{
Mahmoud, M.M*.,Khallaf, M. F. **.;Nessrien, M.N. Yasin** and Abou-Taleb, M*. \\ *National Institute of Oceanography and Fisheries, Fish Processing and Technology Lab., Cairo, Egypt. \\ **Food Science Department, Faculty of Agriculture, Ain Shams Univ., Cairo, Egypt.
}

\begin{abstract}
The aim of this study was to produce fish pastirma from common carp (Cyprinuscarpio) and evaluate the quality of this product. Fish pastirma samples were packed in polyethylene plastic bags and subjected to physicochemical, microbiological and organoleptic analysis at $0,3,6,9,12$ and 15 days of storage at $\left(25 \pm 2^{\circ} \mathrm{C}\right)$ and at $0,7,14,21$ and 30 days of storage at refrigeration condition $\left(5 \pm 1^{\circ} \mathrm{C}\right)$. Results showed that, moisture, protein, fat, ash, carbohydrates and salt contents $\%$ of fresh fish pastirma were 51.80, 21.27, 13.38, 8.54, 5.01 and $7.00 \%$, respectively. There was significant effect at $(\mathrm{p}<0.05)$ of storage conditions on the proximate chemical composition. Also, there was significant at $(\mathrm{p}<0.05)$ incremental pattern in TVB-N values of fish pastirma during both storage conditions with different rates. But, TBA values showed fluctuate pattern at ambient and cold storage. Fish pastirma retained its microbiological quality till the end of storage depends on TBC, coliform as well as molds and yeasts during ambient and cold storage. All fish pastirma accepted and had acceptable limits of its organoleptic properties. Overall acceptability of refrigerated fish pastirma was higher than that stored at ambient temperature till the end of storage periods. Therefore, common carp fish pastirma such as a new product consider one of the successful methods to improve common carp fish utilization, which is undesirable in fresh form because it's sensorial properties and a one of the trials for high production in fish farms for this specie in Egypt.
\end{abstract}

Keywords: fish pastirma, Cyprinuscarpio ,organoleptic microbiological quality, storage conditions.

\section{Introduction}

Fish is a good source of protein and can be used as an alternative to various meats. The reasons are fish its low cholesterol, optimal protein amount, high digestibility and had polyunsaturated fatty acids such as omega-3 as well as essential amino acids (Boran and Köse 2007).Modern life-style demands a consistent food supply with high quality that is convenient as well as affordable (FAO, 2007). Consequently, fish processing has a special concerning in fishing and aquaculture industries. The processing and preservation of fresh fish were important since fish is highly susceptible to deteriorate immediately after harvest and also to prevent economic losses (Okonta and Ekelemu 2005). Common carp (C. carpio) is one of the most widely cultured freshwater fish species all over the world (Vargaet al., 2013).Also, Gökalpet al.(1999); Aktas and Gürses (2005) mentioned that pastirma is categorized as an intermediate moisture food. There is quite work carried out on pastirma produced from red meat animals, but the number of studies on fish pastirma is very limited to show more specification and information of fish pastirma production as cured fish meat similar to cured meat pastirma, the results of previous studies are no sufficient for assessing the quality of fish pastirma. Therefore, the aim of this study was to focus on the production of common carp fish pastirma and to evaluate the quality of such new product. evaluation, physicochemical properties ,

\section{Materials and methods}

\section{Materials:}

The experimental design to process fish pastirma from common carp fish(Cyprinuscarpio L.) fillets was carried by using about $20 \mathrm{~kg}$ from fresh fish, with average weight 3.5 to $5 \mathrm{~kg}$ each and with length 45 to $55 \mathrm{~cm}$ each. Fresh fish were obtained from local market El-QanaterEl-Khiriacity - Qalyoubia governorate, Egypt and transported in icebox to fish processing and technology laboratory. Fish Research Station, El-Kanater El-Khiria, National Institute of Oceanography and Fisheries. Fish were prepared for processing under hygienic condition, all fish were rewashed, beheaded, eviscerated, skinnig removed and filleted, fish fillets were washed and drained. Fish fillets were subjected to chemical and physical analysis to assess freshness parameters.

Fenugreek flour, salt and spices (red pepper and cumin) were obtained from local market, but the mashed garlic used in çemen preparation was prepared from peeled fresh garlic.

\section{Methods: \\ Processing of fish pastirma:}

Fish pastirma sample was processed as follows: about $7.25 \mathrm{~kg}$ fillets (8fillets) from common carp with average weight 800 to $900 \mathrm{~g}$ each, average length from 40 to $45 \mathrm{~cm}$ each and with average thickness $1.5 \mathrm{~cm}$ were used.

Fish fillets were rewashed, drained, salted as dry salting (20 g salt/100 $\mathrm{g}$ fillet), washing to remove 
excess of salt, $1^{\text {st }}$ drying at room temperature by hanging fillet, pressing by mechanical compressor on 2500 Psi G (Pressure cell press U.S.NAMRU-3FRENCH $\left.^{\circledR}\right), 2^{\text {nd }}$ drying at room temperature, coated with çemen: (50\% fenugreek flour, $35 \%$ garlic and $15 \%$ red pepper and sufficient amount of water) as given by Tekinşen and Doğruer (2000).

The coated fillet left until the coated layer completed drying, samples were hanged and left for drying at ambient temperature $\left(25^{\circ} \mathrm{C} \pm 3\right)$ for 5-7 days until coated layer was dried and had about $3 \mathrm{~mm}$ thickness, pastirma samples were packed in open polyethylene bags, which divided for storing at $25 \pm 2^{\circ} \mathrm{C}$ and subjected to organoleptic analysis as fried, physicochemical and microbiological analysis on $0,3^{\text {th }}, 6^{\text {th }}, 9^{\text {th }}, 12^{\text {th }}$ and $15^{\text {th }}$ days and at $5 \pm 1^{\circ} \mathrm{C}$, that subjected to analysis on $0,7^{\text {th }}, 14^{\text {th }}, 21^{\text {th }}$ and $30^{\text {th }}$ days.

\section{Analytical methods:}

\section{Physicochemical analysis:}

The proximate chemical composition as well as moisture, crude protein, fat and ash contents were carried out according to the methods recommended by the AOAC (2000). The salt content of fish pastirma was determined by Mohr method as described by Kenkel (1994).

The chemical quality parameters concluded total volatile basic nitrogen (TVB-N) contents were determined according to the method described by Pearson (1976). While, the thiobarbituric acid (TBA) value was measured according to the method described by Tarladgiset al. (1960). The $\mathrm{pH}$ value was carried out according to the procedure of AOAC (2000).

Microbiological analysis: Total bacterial count (TBC) was determined by using commercial nutrient agar medium (Oxoid CM 0003, OXIOD), coliform bacteria count was determined by using commercial MacConky agar medium, molds and yeasts count were determined by using commercial malt extract agar medium according to the microbiological tests as pour plating method was utilized for microbiological analysis as reported by AOAC (2000); APHA (1992). The microbiological results were represented as $\mathrm{cfu} / \mathrm{g}$.

Sensory analysis: The sensory analysis of fried fish pastirma was carried out according to Amerineet al. (1965); it was done in terms of color, tenderness, taste, flavor and overall acceptability. Fish pastirma was evaluated by 10 panelists from (National Institute of Oceanography and Fisheries, El-Kanater El-Khiria). A 9 point hedonic scale was employed in this sensory analysis. Samples evaluated as fresh processed pastirma and during storage at $25^{\circ} \mathrm{C} \pm 2$ and $5^{\circ} \mathrm{C} \pm 1$. The frying process was done in vegetable oil at $170^{\circ} \mathrm{C}$ for $1 \mathrm{~min}$ for all samples by using electric fryer.

\section{Statistical analysis:}

All measurements were performed in triplicate and values expressed as the mean \pm SD. Statistical analyses were performed using SPSS 18.00 for Windows. Analysis of variance (ANOVA) was used and statistical significance was set at $\mathrm{p}<0.05$ to detect the significant effect between means during storage periods according to (Snedecor and Cochran, 1995).

\section{Results and Discussion}

Proximate chemical analysis of fresh common carp fish and its pastirma during storage at $25 \pm 2^{\circ} \mathrm{C}$ and $5 \pm 1^{\circ} \mathrm{C}$ :

The moisture, protein, fat, ash and carbohydrate contents of fresh common carp fish were $70.47,15.60,12.24,0.68$ and $1.01 \%$ on wet weight basis, respectively as shown Table (1). These results are in the range with those found by Khidhir (2011) and Miroslavet al. (2011). On the other hand, moisture, protein, fat, ash, carbohydrate and salt contents of fresh common carp fish pastirma were $51.80,21.27,13.38,8.54,5.01$ and $7.00 \%(w / w)$, respectively at $25 \pm 2^{\circ} \mathrm{C}$. The proximate chemical analysis attributes of fish pastirma were clearly differed compared to raw fillet; it could be due to the effect of processing steps on fish fillet during processing. As shown in Table (1), the moisture content had a decline pattern in fish pastirma to $51.80 \%$. The protein, fat, ash, carbohydrate and salt contents on wet weight basis showed an opposite trend based on amount of moisture loss and salt uptake. This observation is in agreement with the findings of Nahidet al. (2014). Therefore, ash and salt contents were increased in fish pastirma due to salt absorbed during fillets curing. These results agree with theory of salt uptake and moisture loss, this caused in salt increase in muscle tissue. This emphasized by Andrés et al. (2005) who stated that, when salt brine or dry salt are used as salting agents, two main simultaneous flows are usually generated; water loss and salt uptake. This situation may discussed by Ahmed et al. (2010) who carried out a study on salting 25\% salt (Hydrocynusforskalii) for fish weight and found that lipid content of salted fish was decreased, this might due to the leaching out of some substances during processing as there was direct correlation between leaching out of lipid and protein from muscle and salt muscle concentration. Protein extraction from the muscle has been shown to be a function of the salt concentration, with a maximum at 6-9\% $\mathrm{NaCl}$ (Poernomoet al., 1992 and Lawrie, 1998). From data presented in Table (1), moisture content of fish pastirma during storage at $25 \pm 2^{\circ} \mathrm{C}$ showed a gradually significant $(\mathrm{p}<0.05)$ decline to be $40.73 \%$ at the end of storage period. Also, there were significant $(\mathrm{p}<0.05)$ differences just between samples along 9 days of storage. In opposite protein, fat, ash and salt contents of fish pastirma 
were significantly increased $(\mathrm{p}<0.05)$ with irregular average between days storage compared to the fresh sample to be at the end of ambient storage: 27.50 ,
17.25, 13.87 and $9.20 \%$, respectively, these increments were negatively correlated with the moisture loss.

Table 1. Proximate chemical analysis of fresh common carp fish and its pastirma during storage at $25 \pm 2^{\circ} \mathrm{C}$ (on wet basis).

\begin{tabular}{|c|c|c|c|c|c|c|c|}
\hline \multirow[t]{3}{*}{ Item } & \multirow{3}{*}{$\begin{array}{c}\text { Fresh } \\
\text { fish }\end{array}$} & \multicolumn{6}{|c|}{ Fish pastirma } \\
\hline & & \multicolumn{6}{|c|}{ Storage period (days) } \\
\hline & & $*$ Zero & 3 & 6 & 9 & 12 & 15 \\
\hline \multirow[t]{2}{*}{ \% Moisture } & 70.47 & $51.80^{\mathrm{a}}$ & $49.62^{\mathrm{b}}$ & $48.28^{\mathrm{c}}$ & $41.67^{\mathrm{d}}$ & $41.72^{\mathrm{d}}$ & $40.73^{\mathrm{d}}$ \\
\hline & \pm 0.15 & \pm 0.18 & \pm 0.07 & \pm 0.24 & \pm 0.30 & \pm 0.31 & \pm 0.53 \\
\hline \multirow[t]{2}{*}{$\%$ Protein } & 15.6 & $21.27^{\mathrm{c}}$ & $22.42^{\mathrm{c}}$ & $25.37^{\mathrm{b}}$ & $25.68^{\mathrm{ab}}$ & $26.91^{\mathrm{a}}$ & $27.50^{\mathrm{a}}$ \\
\hline & \pm 0.07 & \pm 0.39 & \pm 0.12 & \pm 0.60 & \pm 0.81 & \pm 0.58 & \pm 0.49 \\
\hline \multirow[t]{2}{*}{$\%$ Fat } & 12.24 & $13.38^{\mathrm{c}}$ & $13.89^{b}$ & $13.80^{\mathrm{b}}$ & $17.30^{\mathrm{a}}$ & $17.29^{\mathrm{a}}$ & $17.25^{\mathrm{a}}$ \\
\hline & \pm 0.08 & \pm 0.11 & \pm 0.18 & \pm 0.01 & \pm 0.04 & \pm 0.04 & \pm 0.09 \\
\hline \multirow[t]{2}{*}{$\%$ Ash } & 0.68 & $8.54^{\mathrm{d}}$ & $12.07^{\mathrm{b}}$ & $11.30^{\mathrm{c}}$ & $11.80^{\mathrm{bc}}$ & $11.32^{\mathrm{c}}$ & $13.86^{\mathrm{a}}$ \\
\hline & \pm 0.02 & \pm 0.04 & \pm 0.26 & \pm 0.02 & \pm 0.15 & \pm 0.10 & \pm 0.23 \\
\hline \multirow[t]{2}{*}{ **\% Total Carbohydrates } & 1.01 & $5.01^{\mathrm{a}}$ & $2.01^{\mathrm{bc}}$ & $1.25^{\mathrm{c}}$ & $3.54^{\mathrm{ab}}$ & $2.77^{\mathrm{bc}}$ & $0.66^{\mathrm{c}}$ \\
\hline & \pm 0.13 & \pm 0.29 & \pm 0.26 & \pm 0.35 & \pm 0.92 & \pm 0.40 & \pm 0.08 \\
\hline \multirow[t]{2}{*}{$\%$ Salt } & - & $7.00^{\mathrm{c}}$ & $7.50^{\mathrm{c}}$ & $7.75^{\mathrm{bc}}$ & $8.50^{\mathrm{ab}}$ & $8.85^{\mathrm{a}}$ & $9.20^{\mathrm{a}}$ \\
\hline & & \pm 0.00 & \pm 0.00 & \pm 0.35 & \pm 0.71 & \pm 0.21 & \pm 0.42 \\
\hline
\end{tabular}

*Fresh fish pastirma

Means \pm Standard error

Means with the same small letters in the same row are not significantly different $(\mathrm{p}<0.05)$

$* *$ Calculated by difference

Table 2. Proximate chemical analysis of fresh common carp fish and its pastirma during storage at $5 \pm 1^{\circ} \mathrm{C}$ (on wet basis).

\begin{tabular}{|c|c|c|c|c|c|c|}
\hline \multirow{3}{*}{ Item } & \multirow{3}{*}{$\begin{array}{c}\text { Fresh } \\
\text { fish }\end{array}$} & \multicolumn{5}{|c|}{ Fish pastirma } \\
\hline & & \multicolumn{5}{|c|}{ Storage period (days) } \\
\hline & & $*$ Zero & 7 & 14 & 21 & 30 \\
\hline \multirow[t]{2}{*}{$\%$ Moisture } & 70.47 & $51.80^{c}$ & $52.59^{\mathrm{b}}$ & $53.41^{\mathrm{a}}$ & $50.38^{d}$ & $53.77^{\mathrm{a}}$ \\
\hline & \pm 0.15 & \pm 0.18 & \pm 0.21 & \pm 0.25 & \pm 0.20 & \pm 0.16 \\
\hline \multirow{2}{*}{$\%$ Protein } & 15.6 & $21.27^{\mathrm{b}}$ & $24.55^{\mathrm{a}}$ & $21.93^{\mathrm{b}}$ & $24.89^{\mathrm{a}}$ & $21.81^{\mathrm{b}}$ \\
\hline & \pm 0.07 & \pm 0.39 & \pm 0.74 & \pm 0.55 & \pm 1.05 & \pm 0.04 \\
\hline \multirow{2}{*}{$\%$ Fat } & 12.24 & $13.38^{\mathrm{a}}$ & $10.17^{\mathrm{c}}$ & $9.96^{\mathrm{c}}$ & $11.10^{\mathrm{b}}$ & $10.26^{\mathrm{c}}$ \\
\hline & \pm 0.08 & \pm 0.11 & \pm 0.03 & \pm 0.11 & \pm 0.26 & \pm 0.02 \\
\hline \multirow{2}{*}{$\%$ Ash } & 0.68 & $8.54^{\mathrm{d}}$ & $10.01^{\mathrm{a}}$ & $9.06^{\mathrm{c}}$ & $8.79^{\mathrm{dc}}$ & $9.74^{\mathrm{b}}$ \\
\hline & \pm 0.02 & \pm 0.04 & \pm 0.13 & \pm 0.12 & \pm 0.02 & \pm 0.04 \\
\hline$* * \%$ Total & 1.01 & $5.01^{\mathrm{ab}}$ & $2.68^{c}$ & $5.64^{\mathrm{a}}$ & $4.83^{\mathrm{ab}}$ & $4.42^{b}$ \\
\hline Carbohydrates & \pm 0.13 & \pm 0.29 & \pm 0.73 & \pm 0.30 & \pm 0.61 & \pm 0.06 \\
\hline \multirow{2}{*}{$\%$ Salt } & & $7.00^{\mathrm{b}}$ & $7.25^{\mathrm{b}}$ & $6.90^{\mathrm{b}}$ & $7.20^{\mathrm{b}}$ & $9.00^{\mathrm{a}}$ \\
\hline & - & \pm 0.00 & \pm 0.35 & \pm 0.14 & \pm 0.14 & \pm 0.28 \\
\hline
\end{tabular}

*Fresh fish pastirma

Means \pm Standard error

Means with the same small letters in the same row are not significantly different $(\mathrm{p}<0.05)$

***Calculated by difference

Table (2) shows the chemical composition of refrigerated common carp fish pastirma. The moisture content was inconsistent during cold storage. Generally, it was significantly increased $(\mathrm{p}<0.05)$ during cold storage, fish pastirma absorbed moisture to be $53.77 \%$ after 30 days of cold storage. There was significant difference $(\mathrm{p}<0.05)$ in protein content, the maximum content of protein was found after 21 days of cold storage $(24.89 \%)$, while the minimum content was at the beginning of storage $(21.27 \%)$. On the other hand, fat content of fish pastirma sample showed significant differences $(\mathrm{p}<0.05)$ during storage periods. Maximum fat content $(13.38 \%)$ was observed at the beginning of cold storage since had a lower moisture content for the same sample. Also, the salt content did not have significant changes $(\mathrm{p}>0.05)$ until reached to $9.00 \%$. Ash content significantly changed during cold storage, it was $11.01 \%$ after 7 days of storage at $5 \pm 1^{\circ} \mathrm{C}$. The carbohydrate content was inconsistent during refrigerated storage. Maximum carbohydrate content was $5.64 \%$ after 14 days of cold storage, while the minimum content was after 7 days $(2.68 \%)$.It has been conclusively established that the 
amount of absorbed water depends primarily on the number and availability of 2 types of hydrophilic groups which are capable for binding water (Aktas and Gürses, 2005). Berkelet al. (2004) stated that, in humid conditions dried fish can take up moisture from the air, forever the variation in net integral enthalpy with the moisture content for pastirma is the net integral enthalpy decreases with increasing moisture content.The ash content changes with the time of storage due to absorbance of moisture and loss of protein (Hassan et al., 2013).

The fat and protein contents of fish pastirma samples were not stable during storage, there were significant differences. Many factors contribute to these changes: the salting, curing and dehydration processes, temperature, spices, time and oxygen abundance are most important factors affecting the physicochemical properties of proteins and lipids (Ahmed et al., 2013)

Physicochemical properties of fresh common carp fish and its pastirma during storage at $25^{\circ} \mathrm{C} \pm 2$ and $5^{\circ} \mathrm{C} \pm 1$ :

The total volatile basic nitrogen (TVB-N) is an important character for the assessment of seafood products quality and appears as the most common chemical indicator of marine fish spoilage. TVB-N which is mainly composed of ammonia and primary, secondary and tertiary amines is widely used as an indicator of fish deterioration (Amegovuet al., 2012).Figures (1\&2) show TVB-N values (mg $\mathrm{N} / 100 \mathrm{~g}$ ) of fresh fish and its pastirma, it were 13.98 and $15.65 \mathrm{mg} \mathrm{N} / 100 \mathrm{~g}$, respectively. This change in TVB-N that found after processing may be reflects the effect of processing conditions on protein degradation as explained byAhmed $\boldsymbol{e t}$ al. (2013) and Ahmed (2014) who reported that,salting, curing and dehydration processes, temperature, spices, time and oxygen abundance are most important factors affecting the physicochemical properties of proteins and lipids.Generally, during storage at both $25 \pm 2^{\circ} \mathrm{C}$ and $5 \pm 1^{\circ} \mathrm{C}$ observed that, the TVB-N values significantly $(\mathrm{p}<0.05)$ increased in all fish pastirma reached to 34.80 and $37.05 \mathrm{mg} \mathrm{N} / 100 \mathrm{~g}$ after 15 and 30 days, respectively. This data go in the same trend obtained by Shiriskaret al. (2010). Also, Estrada et al. (1985) explained that, TVB-N increased during storage at ambient temperature due to proteolysis occurring by spoilage bacteria.

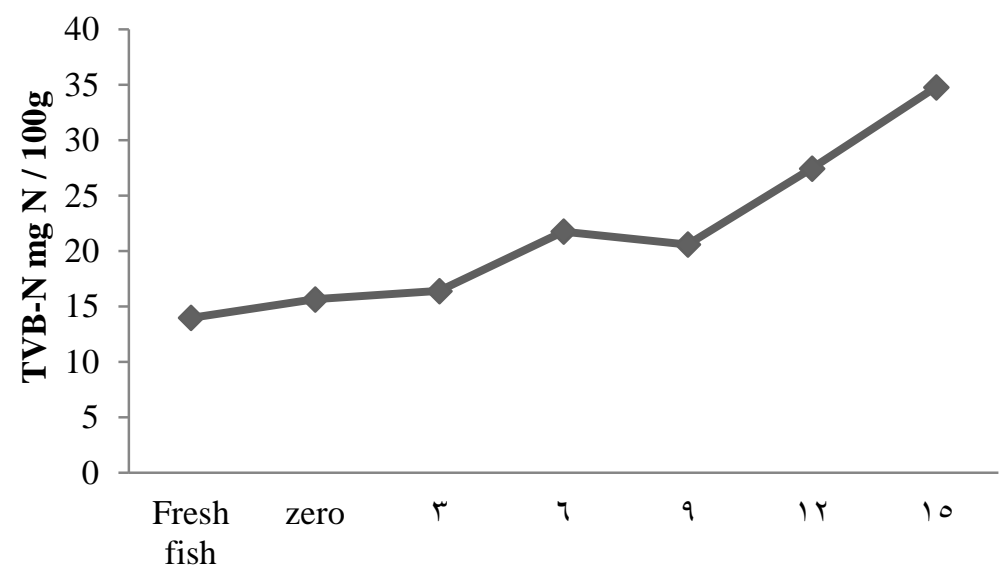

Storage period (days)

Figure (1): Total volatile basic nitrogen of fresh common carp and its pastirma during storage at $25 \pm 2^{\circ} \mathrm{C}$.

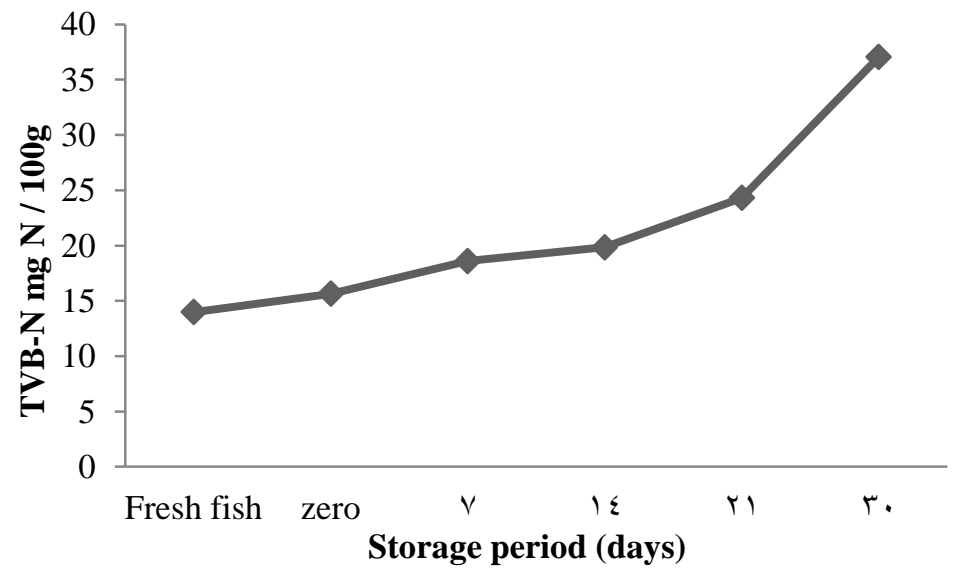

Figure (2): Total volatile basic nitrogen of fresh common carp and its pastirmaduring storage at $5 \pm 1^{\circ} \mathrm{C}$. 
The TVB-N values of fish pastirma stored at $25^{\circ} \mathrm{C} \pm 2$ for 15 days were not exceed the acceptable limit, but TVB-N values of refrigerated fish pastirma after 30 days of storage were higher than permissible limit of acceptability according to Özyurtet al. (2009) who reported that, the limit of acceptability of TVB-N value in fish products was $35 \mathrm{mg} / 100 \mathrm{~g}$ and spoilage starts since it above $35 \mathrm{mg} / 100 \mathrm{~g}$.

Thiobarbituric acid (TBA) value is considered as an indicator for the amount of malonaldehyde; the most predominant secondary oxidation products for food lipids, hence it is considered a good chemical constant for quality assurance and for measuring the extent of the secondary oxidation (autoxidative degradation) of edible lipids during cooking and storage (Hassan and Abu-Arab, 2004). Figures (3\&4) show TBA values (as O.D at $538 \mathrm{~nm}$ ) of fresh fish and fish pastirma. The O.D of fresh fish and fresh fish pastirma were 0.05 and 0.18 , respectively. The increment in TBA value after processing reflected the effect of processing steps on lipids (Ahmed et al., 2013). The TBA value of fish pastirma in this study was fluctuated during different storage periods as shown in Figures(3\&4). The O.D of fish pastirma was significantly decreased after 6 days of storage at ambient temperature then increased after 9 days and reached to 0.18 at the end of storage at $25 \pm 2^{\circ} \mathrm{C}$.

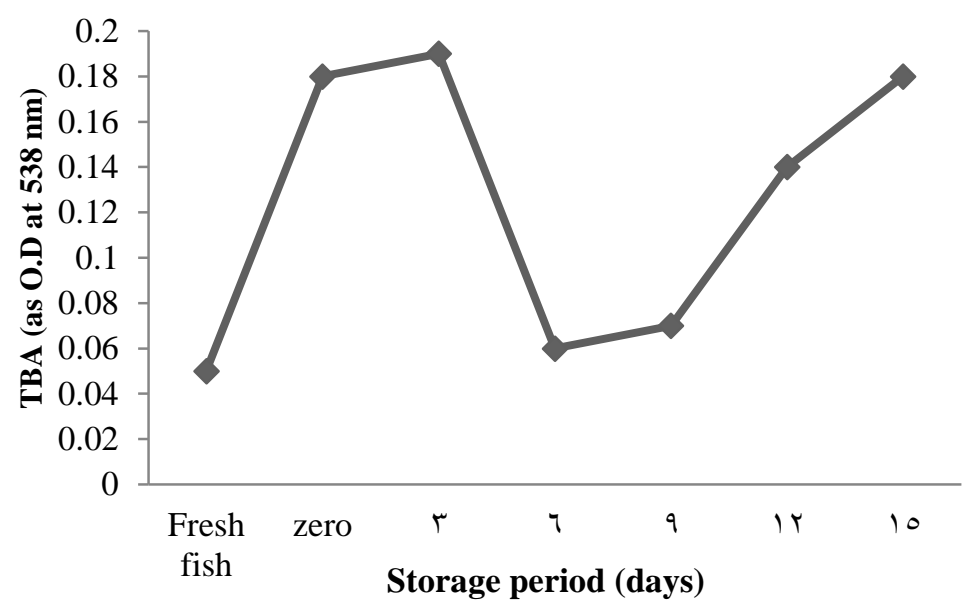

Figure (3): Thiobarbituric acid values of fresh common carp anditspastirmaduring storage at $25 \pm 2^{\circ} \mathrm{C}$.

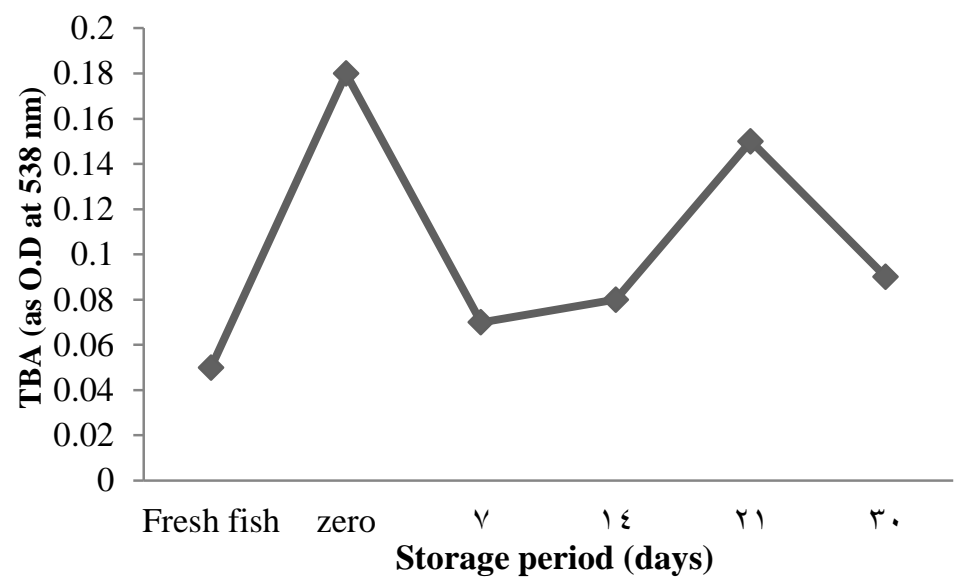

Figure (4): Thiobarbituric acid values of fresh common carp and itspastirmaduring storage at $5 \pm 1^{\circ} \mathrm{C}$.

While, the O.D of fish pastirma during refrigeration storage showed a significant decrease at $7^{\text {th }}$ day of storage $(0.07)$, a significant incremental pattern was found till 21 days then subsequently decreased again after 30 days of cold storage to be 0.09 . Fluctuation in the TBA value of fish pastirmahad been explained by Maqsood and Benjakul (2010) who told that, an initial increase in TBA values likely occurs due to the decomposition of primary oxidation products to secondary oxidation products, whereas a later decrease in TBA values is due to the decomposition of volatile and unstable secondary oxidation products (e.g., malonadehyde and other short-chain carbon products of lipid oxidation) to organic alcohols and acids (which are not measured by the TBA test).Secondary lipid oxidation was studied by the TBA value, which is an index of malonaldehyde concentration.Gadekaret al. (2014) reported that increase in TBA value throughout aerobic storage period might be attributed 
to increase lipid oxidation and production of volatile metabolites in the presence of oxygen.TBA in turkishpastirma as dry cured beef product increased throughout 120 days of storage (Göket al., 2008).

The $\mathrm{pH}$ is an important measurement, which has been commonly used as physical method for quality assessment of fish meat (Mhongole, 2009). $\mathrm{pH}$ value of fresh fish was 6.41 similar with reported by Mhongole (2009) who found the $\mathrm{pH}$ value ranged 6.4 and 7.00. $\mathrm{pH}$ value declined to 6.30 in fresh fish pastirma due to processing treatments such as observed by Gümüş et $\boldsymbol{a l}$. (2008) said that,salting has significant effect on $\mathrm{pH}$ value of salted red mullet fish, salting caused decline in $\mathrm{pH}$ value from 6.67 in fresh fish to 6.51 for salted samples.pH value of fish pastirma showed significant decline $(\mathrm{p}<0.05)$ after 9 days of storage at $25 \pm 2^{\circ} \mathrm{C}$ to be 5.80 at the end of storage as shown in Figure (5), and after 14 days of storage at $5 \pm 1^{\circ} \mathrm{C}(5.95)$ then increased to 6.00 till 30 days of cold storage as shown in Figure (6). Reduction in $\mathrm{pH}$ value during storage was a result of the activity of lactic acid bacteria (El-Khateibet al., 1987).

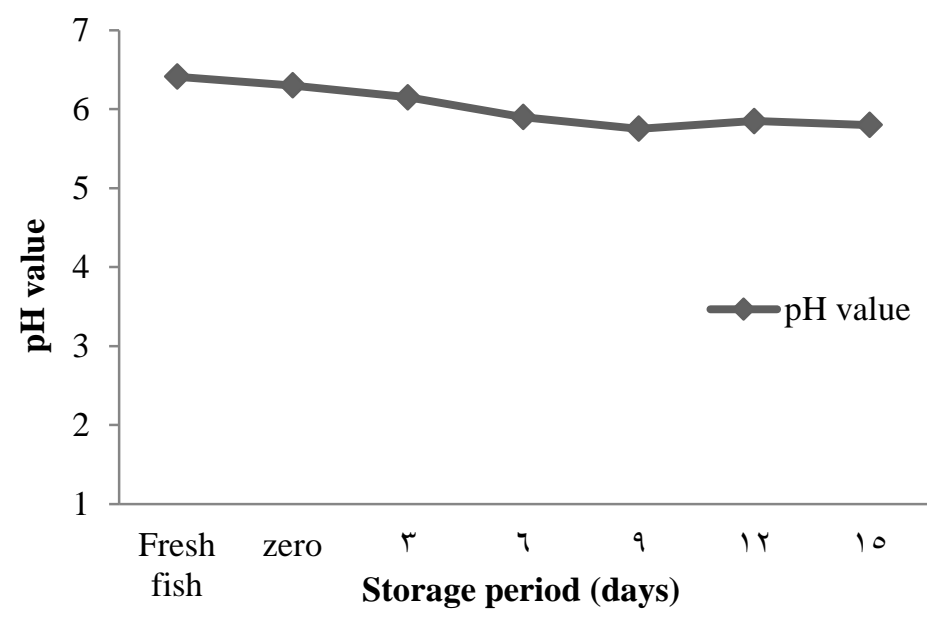

Figure (5): $\mathrm{pH}$ values of fresh common carp and its pastirma during storage at $25 \pm 2^{\circ} \mathrm{C}$.

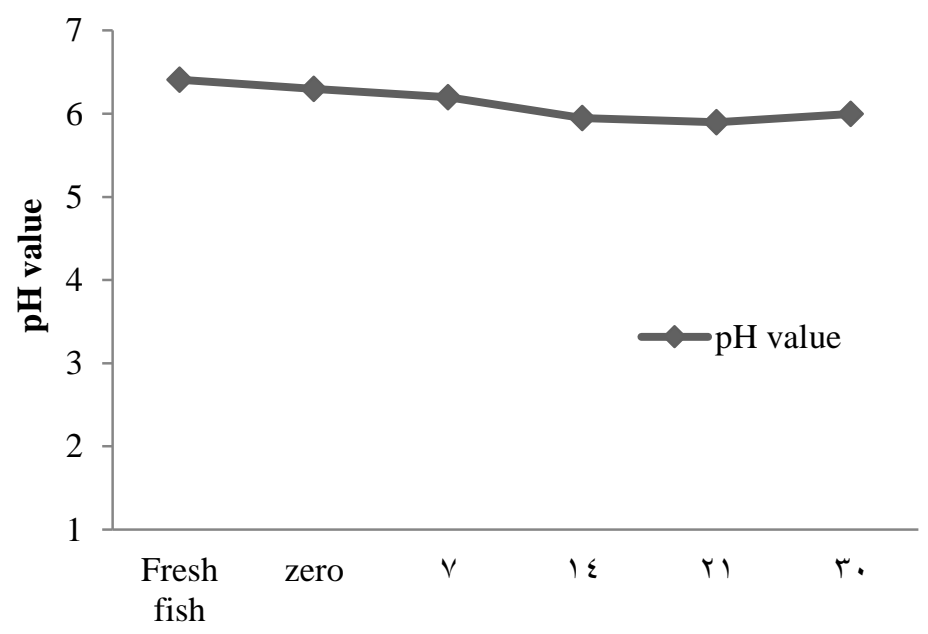

Storage period (days)

Figure (6): $\mathrm{pH}$ values of fresh common carp and its pastirma during storage at $5 \pm 1^{\circ} \mathrm{C}$.

\section{Microbiological analysis of fish pastirma:}

As seen in Table (3) the numbers of total bacterial count $(\mathrm{TBC})$, coliform and molds and yeasts of fresh fish pastirma were $9 \times 10^{3}, 5 \times 10^{1}$ and $5 \times 10^{1} \mathrm{cfu} / \mathrm{g}$, respectively. The TBC of fish pastirma increased significantly $(\mathrm{p}<0.05)$ by different averages to reach to maximum count $\left(46 \times 10^{3} \mathrm{cfu} / \mathrm{g}\right)$ after 9 days of storage at $25 \pm 2{ }^{\circ} \mathrm{C}$, after that a significant decline was recorded to be $25 \times 10^{3} \mathrm{cfu} / \mathrm{g}$ at 15 days of storage. However, there was a gradually significant increment $(\mathrm{p}<0.05)$ in TBC numbers of common carp fish pastirmaand reached to $44 \times 10^{3}$ $\mathrm{cfu} / \mathrm{g}$ at the end of storage at $5^{\circ} \mathrm{C} \pm 1$ (Table 4).

Generally, the TBC numbers in investigated fish pastirma were under the spoilage limit according to Gill (1983) who reported that meat spoilage does not occur until the total bacterial count reaches a level of $10^{6-8} \mathrm{organism} / \mathrm{g}$. In addition, the coliform counts were $<10 \times 10 \mathrm{cfu} / \mathrm{g}$ at both storage conditions as appeared in Tables ( $3 \& 4)$, moreover coliform were not detected after $21 \& 30$ days of cold storage. 
Table 3. Microbiological quality of common carppastirma during storage at ambient temperature $\left(25 \pm 2^{\circ} \mathrm{C}\right)$.

\begin{tabular}{|c|c|c|c|c|c|c|}
\hline \multirow{2}{*}{$\begin{array}{c}\text { Microbiological } \\
\text { test }\end{array}$} & \multicolumn{6}{|c|}{ Storage period (days) } \\
\hline & Zero & 3 & 6 & 9 & 12 & 15 \\
\hline & $9.00^{e}$ & $20.00^{d}$ & $34.00^{b c}$ & $46.00^{\mathrm{a}}$ & $36.00^{b}$ & $25.00^{\mathrm{cd}}$ \\
\hline ТВС (cfu $\left.\times 10^{\%} / \mathrm{g}\right)$ & \pm 1.00 & \pm 4.00 & \pm 2.00 & \pm 2.00 & $\pm \mathbf{3 . 0 0}$ & \pm 4.00 \\
\hline Coliform & $5.00^{\mathrm{a}}$ & $2.00^{\mathrm{a}}$ & $6.00^{a}$ & $5.00^{\mathrm{a}}$ & $4.00^{\mathrm{a}}$ & $7.00^{\mathrm{a}}$ \\
\hline$($ cfu x10/g) & \pm 1.00 & \pm 1.00 & \pm 1.00 & \pm 1.00 & \pm 2.00 & \pm 1.00 \\
\hline Molds \&Yeasts & $\mathbf{5}^{\mathbf{a}}$ & $2.00^{\mathrm{a}}$ & $7.5^{\mathrm{a}}$ & $5.00^{\mathrm{a}}$ & $5.00^{\mathrm{a}}$ & $3.00^{\mathrm{a}}$ \\
\hline$(\mathrm{cfu} \times 10 / \mathrm{g})$ & \pm 3 & \pm 1.00 & \pm 1.00 & \pm 1.00 & \pm 2.00 & \pm 1.00 \\
\hline
\end{tabular}

Means \pm Standard error

Means with the same small letters in the same row are not significantly different $(\mathrm{p}<0.05)$

Table 4. Microbiological quality of common carp fish pastirma during storage at refrigeration $\left(5 \pm 1^{\circ} \mathrm{C}\right)$.

\begin{tabular}{|c|c|c|c|c|c|}
\hline \multirow{2}{*}{$\begin{array}{c}\text { Microbiological } \\
\text { tests }\end{array}$} & \multicolumn{5}{|c|}{ Storage period (days) } \\
\hline & Zero & 7 & 14 & 21 & 30 \\
\hline TBC $\left(\mathrm{cfu} \times 10^{3} / \mathrm{g}\right)$ & $\begin{array}{c}9.00^{\mathrm{c}} \pm \\
1.00\end{array}$ & $\begin{array}{l}13.00^{c} \pm \\
2.00\end{array}$ & $\begin{array}{l}15.00^{c} \pm \\
2.00\end{array}$ & $\begin{array}{l}28.00^{b} \pm \\
4.00\end{array}$ & $\begin{array}{l}44.00^{\mathrm{a}_{ \pm}} \\
1.00\end{array}$ \\
\hline $\begin{array}{c}\text { Coliform } \\
\text { (cfu x10/g) }\end{array}$ & $\begin{array}{c}5.00^{\mathrm{ab}} \pm \\
1.00\end{array}$ & $\begin{array}{c}6.00^{\mathrm{a}} \pm \\
0.00\end{array}$ & $\begin{array}{c}2.00^{\mathrm{bc}_{ \pm}} \\
2.00\end{array}$ & nd & nd \\
\hline $\begin{array}{l}\text { Molds \&Yeasts } \\
\text { (cfu x10/g) }\end{array}$ & $\begin{array}{c}5.00^{c} \pm \\
3.00\end{array}$ & $\begin{array}{l}10.00^{c} \pm \\
1.00\end{array}$ & $\begin{array}{c}11.00^{\mathrm{bc}_{ \pm}} \\
1.00\end{array}$ & $\begin{array}{c}17.00 a^{b} \pm \\
1.00\end{array}$ & $\begin{array}{r}19.00^{a} \pm \\
2.00 \\
\end{array}$ \\
\hline
\end{tabular}

Means \pm Standard error

Means with the same small letters in the same row are not significantly different $(\mathrm{p}<0.05)$

nd not detected

The mold and yeast numbers were not significant changed between fish pastirma samples during storage at ambient temperature. However, molds \& yeasts were significantly increased by inconsistent rates during 30 days of cold storage. Coliform, yeast and mold counts were $<10^{1} \mathrm{cfu} / \mathrm{g}$ in all the samples.

\section{Sensory evaluation of fish pastirma:}

The sensory evaluation of fish pastirma was carried out by evaluating some sensory attributes such: color, tenderness, taste, flavor and overall acceptability after frying. Figures (7\&8) revealed that, the mean score of color was good since color scores was $>5$ and $<7$ in fresh processed fish pastirma but the color of fried fish pastirma showed significant decline $(\mathrm{p}<0.05)$ to be fair when color score was $<6$ after 3 and 12 days of storage at $25 \pm 2^{\circ} \mathrm{C}$. The color of fried fish pastirma was good during cold storage. Çakiciet al. (2015) reported that, the color of pastirma types is one of the most important quality attributes, and the acceptability of sliced pastırma is a common concern attribute in both by producers and consumers. In addition, the average point's color of fish pastirma in this study during cold storage retained its color better than the samples stored at ambient temperature. The highest score of color was 7.80 observed in fried fish pastirma after 6 day of storage at $\left(25 \pm 2^{\circ} \mathrm{C}\right)$ as presented in Figure (7). The color values of pastirma types are affected by a lot of factors such as the properties of the raw material (myoglobin and fat levels of muscle, etc.), curing methods and time, curing compounds, storage time and temperature, microbiological counts of pastirma and packaging type (Aksu and Kaya 2002).

On the other hand, fresh fish pastirma after frying was moderately tender when the tenderness score was less than 9 and over than 5 but it showed a significant decline to be slightly tender since tenderness score was less than 5 after 3 and 12 days of storage at $25 \pm 2^{\circ} \mathrm{C}$. The refrigerated fish pastirma were moderately tender until the end of cold storage (30 days). In the same trend, the flavor of pastirma that is a key attribute for consumers' acceptance and marketing. Usinginstrumental and sensory analysis, many aspects of pastirma flavor would have to characterize. The enzyme-mediated transamination can synthesize by degrading proteins some aromatic amino acids that are the source of flavor (Ahmed, 2014). 


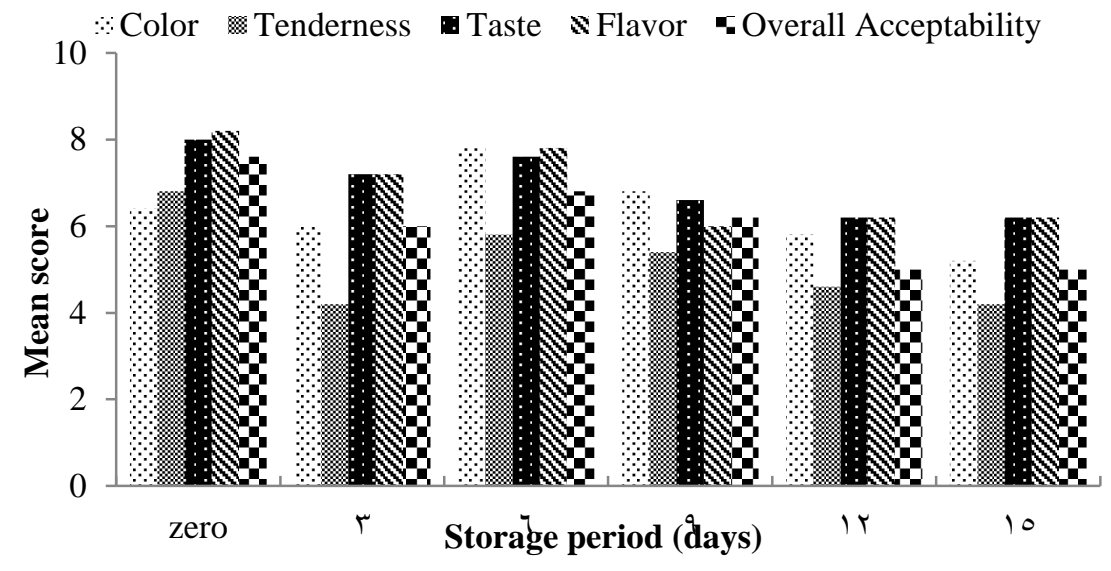

Figure (7): Sensory evaluation of fried common carp pastirma during storage at ambient temperature $25 \pm 2^{\circ} \mathrm{C}$.

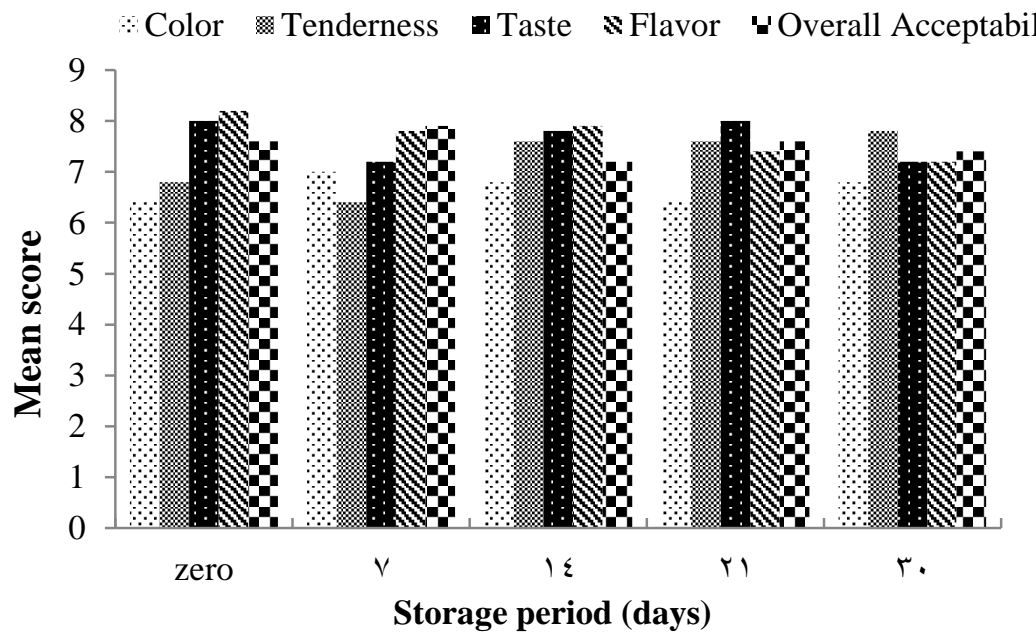

Figure 8. Sensory evaluation of fried common carp pastirma during storageat refrigeration $5 \pm 1^{\circ} \mathrm{C}$.

The taste and flavor showed the same trend and had the highest scores in fresh fish pastirma (zero time). The taste score was full and the flavor were moderately since its score about or over than 7 in all fish pastirma samples. It is worth to mention that, the best acceptability of fried fish pastirma was observed in fresh (zero time) and in cold stored samples. However, all attributes of sensory analysis were in acceptable limits, moreover the overall acceptability was high in refrigerated fish pastirma. Fish pastirma was accepted after 15 days of storage at ambient temperature and till 30 day of cold storage. The highest score was 7.90 in fried sample which contained $52.59 \%$ moisture at the $7^{\text {th }}$ day of storage at $5^{\circ} \mathrm{C} \pm 1$ and the lowest one was 5.00 in fried sample which contained 41.72 and $40.73 \%$ moisture at the $12^{\text {th }}$ and $15^{\text {th }}$ days of storage at $25^{\circ} \mathrm{C} \pm 2$, respectively.

Finally, it could be concluded that fish pastirma was microbiologically and sensorially accepted after 30 days of cold storage; however its TVB-N value was exceeded on the acceptable limit. But, storage at ambient temperature recorded high scores of overall acceptability until 15 days of storage. However, TVB-N value was not exceeded acceptable limit till the end of storage.

\section{Reference}

Ahmed, E.O.; Ali, M. E. and Hamed, A.A. (2010). Quality changes of salted kass (Hydrocynusforskalii) during storage at ambient temperature $\left(37 \pm 1^{\circ} \mathrm{C}\right)$. Pakistan Journal of Nutrition, 9 (9): 877-881.

Ahmed, M.A.; Kaneko, G.; Ushio, H.; Inomata, T.; Yetim, H.; Karaman, S.; Muguruma, M. and Sakata, R. (2013). Changes in physicochemical properties of proteins in KayserianPastirma made from the $M$. semimembranosus muscle of cows during traditional processing. Food Science and Human Wellness, 2 (1): 46-55.

Ahmed, M. A. (2014). Traditional cured meatmaking process degrades the proteins of $\mathrm{M}$. latissimusdorsi of bovine. International Food Research Journal 21(1): 139-148.

Aksu, M. I. and Kaya, M. (2002). Production of pastırma with different curing methods and using starter culture.Turkish Journal of Veterinary \& Animal Science, 26:909-916. 
Aktas, N. and Gürses, A. (2005).Moisture adsorption properties and adsorption isosteric heat of dehydrated slices of pastirma (Turkish dry meat product). Meat Sci., 71:571-576.

Amegovu, A. K.; Sserunjogi, M. L.; Ogwok, P. and Makokha, V. (2012).Nucleotited degradation products, total volatile basic nitrogen, sensory and microbiological quality of Nile pearch (Latesniloticus) fillets under chilled storage. Journal of microbiology, biotechnology and food sciences, 2: 653-666.

Amerine, M.A.; Pangborn, R.M. and Rocssler, E.B. Gök, V.; Obuz, E. and Akkaya, L. (2008). Effects (1965). Principles of sensory evolution of foods, pp: 349, Academic press, New York

Andrés, A.; Rodríguez-Barona, S.; Barat, J. M. and Fito, P. (2005). Salted cod manufacturing: influence of salting procedure on process yield and product characteristics. Journal of Food Engineering, 69: 467-471.

AOAC.(2000). Official Methods of Analysis of the Association of Analytical Chemists. $18^{\text {th }}$ Ed., Washington, D.C., USA.

APHA. (1992). American Publish Health Association Compendium of Methods for the Microbiological Examination of Foods. Washington D.C, USA.

Berkel, B.M.; Boogaard, B.V. and Heijnen, C. (2004).Preservation of Fish and Meat.Agromisa Foundation, Wageningen, The Netherlands, Pp: 26-28.

Boran, M. and Köse, S. (2007).Storage properties of three types of fried whiting balls at refrigerated temperatures. Turkish Journal of Fisheries and Aquatic Sciences, 7:65-70.

Çakici, N.; Aksu, M. I. and Erdemir, E. (2015).A survey of the physico-chemical and microbiological quality of different pastirma types: a dry-cured meat product. CyTA, Journal of Food, (13)2: 196203.

El-Khateib, T.; Schmidt, U. and Leistner, L. (1987).Mikrobiologischestabilitat von turkischerpastirma.Fleischwirtsch, 67(1): 101105. C.F.Kök, F.; Goksoy, O.E. and Gonulalan, Z. (2009). The microbiological, chemical and sensory features of vacuumedpacked wels catfish (Silurusglanis L.) pastrami stored under ambient conditions $\left(20^{\circ} \mathrm{C}\right)$. Journal of Animal and Veterinary Advances, 8(4):817824.

Estrada, M.M.; Olympia, R.; Mateo, A. and Embuscado, M. (1985). Mesophilic spoilage of whiting (Sillago maculate) and Tilapia (Oreochromisniloticus). In Spoilage of Tropical Fish and Product Development (Reilly, A. ed.). Food and Agricultural Organization of the United Nations, (Rome), 1:134-142.

FAO.(2007). Food and Agricultural Organization. The State of World Fisheries and Aquaculture 2006 . In: Trash or Treasure? Low-value/trash fish from marine fisheries in the Asia-Pacific
region.FAO Fisheries and Aquaculture Department, Rome, Italy. pp. 115-120.

Gadekar, Y.P.; Sharma, B.D.; Shinde, A.K.; Verma, A.K. and Mendiratta, S.K. (2014).Effect of natural antioxidants on the quality of cured, restructured goat meat product during refrigerated storage $\left(4 \pm 1^{\circ} \mathrm{C}\right)$, Small Ruminant Research, 119 :72-80.

Gill, C.O. (1983). Meat spoilage and evaluation of the potential storage life of fresh meat. J Food Protect.,46:444-542.

of packaging method and storage time on the chemical, microbiological and sensory properties of Turkish pastirma-a dry cured beef product. Meat Science, 80:335-344.

Gökalp, H. Y.; Kaya, M. and Zorba, O. (1999). Technology of pastirma and some other dried products: Engineering of Meat Products Processing, $3^{\text {rd }}$ Press (pp. 309-339), Atatürk Univ. Publ. No. 786, Faculty of Agric. No. 320, Atatürk University, Erzurum, Turkey.

Gümüş, B.; İkiz, R.; Ünlüsayin, M. and Gülyavuz, H. (2008). Quality Changes of Salted Red Mullet (MullusbarbatusL., 1758) During Vacuum Packaged Stored at $+4^{\circ} \mathrm{C}$. Journal of Fisheries \& Aquatic Sciences, 2: 101-104.

Hassan, I.M. and Abou-Arab, A.A. (2004). Estimation of quality attributes and frying times of cotton seed and sunflower oils blend during deep-fat frying of potato chips. Alex. J. Food Sci. and Techn., 1(2): 13-21.

Hassan, M.N.; Rahman, M.;Hossain, M.M.; Nowsad, A.M. and Hossain, M.B. (2013). Post-harvest loss and shelf life of traditionally smoked shrimp products produced in Bangladesh, World J. of Fish and Marine Sci.,5(1):14-19.

Kenkel, J. (1994). Analytical Chemistry for Technicians $2^{\text {nd }}$ Edition, Lewis publishers, Boca Raton.Florida USA.

Khidhir, K.Z. (2011) .Comparative Quality Assessments of Five Local Fresh Fish in Sulaimani City Markets, Ph.D Thesis, College of Veterinary Medicine, University of Sulaimani. Iraq.

Lawrie, R.A. (1998). The storage and preservation of meat II.Moisture control. In: Lawrie's Meat Science, $6^{\text {th }}$ edn. (edited by R.A. Lawrie). Pp. 191-194. Woodhead,Cambridge, UK: PublishingLimited.

Maqsood, S. and Benjakul, S. (2010). Synergistic effect of tannic acid and modified atmospheric packaging on the prevention of lipid oxidation and quality losses of refrigerated striped catfish slices. Food Chemistry, 121: 29-38.

Mhongole, J. M. (2009). Microbiology and spoilage trail in Nile perch (Latesniloticus), Lake Victoria, Tanzania. MSc. Thesis, Food Science (Seafood Processing).Faculty of Food Science 
and Nutrition School of Health Sciences.University of Iceland.

Miroslav, Ć.; Dejana, T.; Dragana, L. andVesna, Đ. (2011). Meat quality of fish farmed in polyculture in carp ponds in Republic of Serbia.International $56^{\text {th }}$ Meat Industry Conference held from June $12-15^{\text {th }}$. Tara mountain, on (tehnologija mesa) :106-121.

Nahid, M.N.; Latifa, G.A.; Farid, F.B. and Begum, M. (2014).Evaluation of biochemical composition of salt and garlic treated smokedried chapila (GudusiachapraHamilton, 1822) and kaika (XenentodoncancilaHamiltonBuchanan, 1822) fish at laboratory condition $\left(27-31^{\circ} \mathrm{C}\right)$. Research Journal of Animal, Veterinary and Fishery Sciences, 2(10):10-15.

Okonta, A.A. and Ekelemu, J.K. (2005). A preliminary study of micro-organisms associated with fish spoilage in Asaba, southern Nigeria.Proceedings of the $20^{\text {th }}$ Annual Conference of the Fisheries Society of Nigeria
(FISON), Port Harcourt, 14th-18th November, pP: 557-560.

Özyurt, G.; Kuley, E.; Özkütük, S. and Özogul, F. (2009).Sensory, microbiological and chemical assessment of the freshness of red mullet (Mullusbarbatus) and goldband goatfish (Upeneusmoluccensis) during storage in ice. Food Chemistry, 114: 505-510.

Pearson, D. (1976). The Chemical Analysis of Food .Chem.Pub.Comp.Inc., New York, USA.

Poernomo, A.; GyatmiFawzya, Y. N. and Ariyani, F. (1992). Salting and drying of Mackerel (RastrelligerKanagurta). ASEAN Food Journal, (7): 141-146.

Shiriskar, D.A.; Khedkar, G.D. and Sudhakara, N.S. (2010).preparation of pickled product from anchovies (Stolephorus sp.) and studies on quality changes during storage, Journal of Food Processing and Preservation, 34:176-190.

Snedecor, G.W., Cochran, W.G. (1995). Statistical Methods, 8th ed. Oxfordand IBH Publishing Co, New Delhi, pp. 45-97.

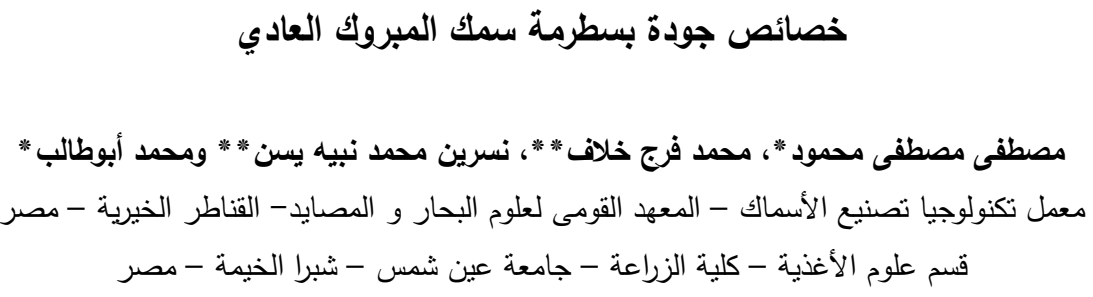

إستهدفت هذه الدراسة إنتاج بسطرمة سمك من شرائح أسماك المبروك العادى وتقييم جودة هذا المنتج عن طريق التقديرات الفيزوكيمبائية

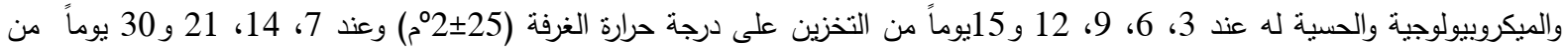

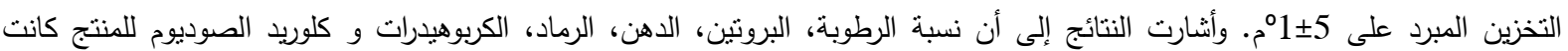

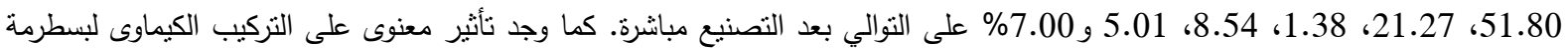

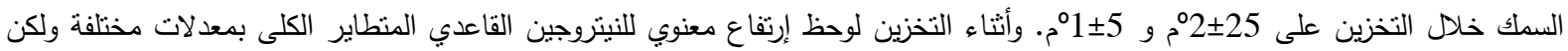
كانت قيم رقم حامض الثيوباربيتوريك مقدرة ككثافة ضوئية على طول موجى 538 نانومتز غير مستقرة خلال فترات التخزين على درجة حرارة الغرفة والتخزين المبرد. كما ظل المنتج محتفظاً بجودته الميكروبيولوجية حتى نهاية فترتى التخزين إستتاداً على قيمة العد الكلى للبكتيريا والخمائر والفطريات ومجموعة بكتبريا القولون. كما لوحظ أن جميع عينات بسطرمة السمك كانت عند مستويات القبول لخصائصها الحسية وأعطت بسطرمة الفينة السمك المخزنة بالتبريد قيماً أعلى من حيث القبول العام مقارنة بالمخزنة على درجة حرارة الغرفة وذلك حتى نهاية التخزين. وبذلك يعتبر هذا المنتج الجديد أحد الوسائل الناجحة فى الإستفادة من سمك المبروك العادي ذو الخصائص الحسية غير المرغوبة فى صورته الطازجة وأحد

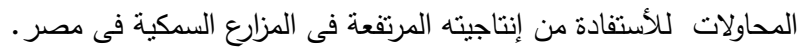

